\title{
PENGARUH LAMA PEMASAKAN TERHADAP KADAR PROTEIN, LEMAK, PROFIL ASAM AMINO, DAN ASAM LEMAK TEPUNG IKAN SEPAT RAWA (Trichogaster trichopterus)
}

\author{
Rabiatul Adawyah, Siti Khusnul Khotiffah, Wahyudinur, Findya Puspitasari \\ Program Studi Teknologi Hasil Perikanan, Jurusan Pengolahan Hasil Perikanan \\ Fakultas Perikanan dan Kelautan, Universitas Lambung Mangkurat \\ Jalan A. Yani, km 36, Banjarbaru, 70714 \\ ${ }^{\star}$ Korespondensi: findya.p@gmail.com \\ Diterima:18 Juni 2020/Disetujui: 13 Juli 2020
}

Cara sitasi: Adawyah R, Khotiffah SK, Wahyudinur, Puspitasari F. 2020. Pengaruh lama pemasakan terhadap kadar protein, lemak, profil asam amino, dan asam lemak tepung ikan sepat rawa. Jurnal Pengolahan Hasil Perikanan Indonesia. 23(2): 286-294.

\begin{abstract}
Abstrak
Populasi ikan sepat rawa (Trichogaster trichopterus) di Provinsi Kalimantan Selatan melimpah namun masih belum dimanfaatkan secara maksimal. Pengolahan ikan sepat rawa menjadi tepung ikan diharapkan dapat memaksimalkan pemanfaatannya. Penelitian ini bertujuan untuk menganalisis pengaruh perbedaan lama pemasakan pada proses pengolahan tepung ikan terhadap kadar protein, kadar lemak, profil asam amino, dan asam lemak tepung ikan sepat rawa. Penelitian menggunakan metode Rancangan Acak Lengkap (RAL) dengan perlakuan pemasakan. Perlakuan yang diberikan adalah pemasakan menggunakan panci selama 30 menit (A), autoklaf 20 menit (B) dan autoklaf 30 menit (C). Hasil penelitian menunjukkan perlakuan memberikan pengaruh terhadap kadar protein dan lemak, serta profil asam amino dan asam lemak. Kadar protein paling tinggi pada perlakuan C sebesar 63,76\%, kadar lemak terendah pada perlakuan B sebesar 3,53\%. Untuk profil asam amino, lisin merupakan jenis asam amino esensial paling tinggi dari profil asam amino penyusun protein tepung ikan, sedangkan jenis asam amino non esensial tertinggi adalah asam glutamat, dan pada profil asam lemak terdapat 23 jenis asam lemak, tertinggi adalah asam palmitat sebesar $21,66 \%$, asam oleat $\mathrm{d}$ sebesar $17,49 \%$ dan asam linoleat sebesar $6,69 \%$.
\end{abstract}

Kata kunci: asam amino, asam lemak, lemak, protein, sepat rawa, tepung ikan

\section{Effect of Different Cooking Time on Protein and Fat Content, Amino Acid and Fatty Acid Profile of Three Spot Gourami (Trichogaster trichopterus) Fish Flour}

\begin{abstract}
Three spot gourami (Trichogaster trichopterus) population in South Kalimantan is abundant but not yet utilized optimally. Processing three spot gourami into fish flour is expected to maximize its utilization. This study aimed to understand the effect of different cooking time in three spot gourami fish flour processing on protein and fat content, amino acid, and fatty acid profile. The design of this study was experimental with a completely randomized design method. The protein content was analyzed by kjeldahl method, amino acid analyzed by High Performance Liquid Chromatography (HPLC) method, lipid content analyzed by the soxhlet method and fatty acid analyzed by Gas Chromatography (GC). The treatments used were cooking using a pan for 30 minutes (A), autoclave 20 minutes (B), and autoclave 30 minutes (C). The results showed the treatment affected protein and fat content, as well as amino acid and fatty acid profiles. The highest protein content in treatment C $63.76 \%$, the lowest fat content in treatment B 3.53\%. For the amino acid profile, lysine is the highest type of essential amino acid, while the highest type of nonessential amino acid is glutamic acid, and in the fatty acid profile there are 23 types of fatty acids, the highest is palmitic acid with an average $21.66 \%$, followed by oleic acid d $17.49 \%$ and linoleic acid $6.69 \%$.
\end{abstract}

Keywords : amino acid, lipid, fatty acid, fish flour, protein, three spot gourami 


\section{PENDAHULUAN}

Ikan sepat rawa khususnya pada Provinsi Kalimantan Selatan sangat melimpah. Hasil produksi ikan tersebut di Provinsi Kalimantan Selatan berjumlah sekitar $1.951,8$ ton pada perairan sungai dan pada perairan rawa sebesar 3.051,7 ton (Dinas Kelautan dan Perikanan 2017). Melimpahnya ikan tersebut belum dimanfaatkan dengan maksimal. Sebagian masyarakat kerap memanfaatkan ikan tersebut sebagai konsumsi sehari-hari, ada juga yang memanfaatkannya sebagai produk olahan di antaranya ikan sepat kering dan bekasam yang pengolahannya masih sangat tradisional, bahkan ada yang hanya menjadikannya pakan ternak ketika musim ikan sangat melimpah.

Nilai ekonomis ikan sepat rawa (Trichogaster trichopterus) cukup tinggi, meskipun pemanfaatannya belum optimal di Kalimantan Selatan. Ikan ini biasanya dijual dalam keadaan segar di pasar, ada juga yang mengawetkan menjadi ikan asin, bekasam dan sebagainya (Murjani 2011). Ikan merupakan salah satu komoditas hasil perairan yang sangat potensial karena keberadaannya sebagai bahan pangan dapat diterima oleh berbagai lapisan masyarakat. Hal ini karena ikan memiliki kandungan gizi yang baik khususnya memiliki kandungan protein yang tinggi dan mengandung asam amino esensial yang diperlukan oleh tubuh. Selain itu, nilai biologisnya yang mencapai $90 \%$ dan memiliki jaringan pengikat yang sedikit sehingga mudah dicerna dan yang paling penting adalah harganya jauh lebih terjangkau oleh masyarakat dibandingkan sumber protein hewani lainnya.

Pengolahan ikan sepat rawa menjadi tepung ikan diharapkan dapat memaksimalkan pemanfaatan produksi ikan sepat rawa yang melimpah selain diolah menjadi ikan kering, bekasam, dan produk lainnya. Menurut Pratiwi (2013), upaya mengeluarkan sebagian air dan lemak dalam ikan bisa menghasilkan produk padat yang kemudian disebut tepung ikan. Tepung tersebut biasanya akan disimpan sebelum dimanfaatkan sebagai bahan tambahan untuk produk jadi, sehingga penting untuk menjaga kualitasnya. Tepung ikan dapat disimpan lebih lama, dalam proses pendistribusian lebih praktis, dan dapat diolah menjadi berbagai macam produk pangan yang diinginkan masyarakat. Tepung ikan dapat dimanfaatkan sebagai fortifikasi sumber zat gizi dari ikan (Adeleke et al. 2010; Desai et al. 2018) sehingga dapat memenuhi kebutuhan gizi masyarakat khususnya protein.

Ikan merupakan sumber protein hewani yang bermanfaat sebagai pengganti sel-sel yang rusak yang diperlukan oleh tubuh selama proses pertumbuhan (Astawan 2004). Hal ini seperti yang dikemukakan oleh Larsen et al. (2011) ditinjau dari sisi nutrisi protein yang baik kandungan asam aminonya lengkap dan daya cernanya tinggi.

Keberadaan asam lemak memberikan beragam manfaat seperti membantu dalam menghasilkan energi serta sebagai zat penyusun tubuh. Di alam, asam-asam lemak sering ditemukan memiliki nomor atom genap, rantai tidak bercabang dengan bentuk asam-asam monokarboksilat. Asam lemak digolongkan menjadi dua yaitu jenuh dan tak jenuh (Liputo et al. 2013).

Menurut Adawyah (2016), salah satu cara untuk membuat bahan pangan menjadi lunak yaitu dengan cara menggunakan suhu dan tekanan tinggi yang disebut dengan pengolahan presto. Saparinto (2007) menyatakan bahwa produk dengan tulang yang menjadi lunak dihasilkan dengan pemasakan menggunakan presto dengan tekanan dan suhu yang tinggi sehingga memudahkan untuk dikonsumsi dan pengolahan produk lanjutan dari ikan presto berduri lunak tersebut. Beberapa penelitian tentang perubahan komposisi kimia akibat perlakuan suhu tinggi telah banyak dilaporkan di antaranya adalah proses pengukusan rajungan (Jacoeb et al. 2012), perebusan udang ronggeng (Jacoeb et al. 2008), pengukusan kakap merah (Jacoeb et al. 2013), perebusan kerang pokea (Yenni et al. 2012), pemanfaatan tulang ikan belida sebagai sumber kalsium (Kusumaningrum et al.2016), embal fortifikasi (Riry et al. 2016), fortifikasi ikan patin pada snack (Nurilmala et al. 2014), stik sepat siam 
(Sari et al. 2019), dan proses penggorengan pada ikan cakalang (Nurjanah et al. 2015).

Penelitian ini bertujuan untuk menentukan pengaruh waktu dan suhu pemasakan pada proses pengolahan tepung ikan terhadap kadar protein dan lemak, serta profil asam amino dan asam lemak tepung ikan yang dihasilkan. Sedangkan kegunaannya adalah untuk memberikan informasi terhadap masyarakat mengenai pemanfaatan dan diversifikasi olahan ikan sepat rawa serta memperoleh data tentang pengaruh perbedaan lama pemasakan terhadap kadar protein, kadar lemak, profil asam lemak, dan profil asam amino tepung ikan sepat rawa.

\section{BAHAN DAN METODE Bahan dan Alat}

Ikan sepat rawa merupakan bahan baku utama. Analisis kadar protein menggunakan bahan selenium, $\mathrm{H}_{2} \mathrm{SO}_{4}$ pekat, akuades, asam borat $\left(\mathrm{H}_{3} \mathrm{BO}_{3}\right) 2 \%, \mathrm{NaOH} 40 \%, \mathrm{HCl} 0,1 \mathrm{~N}$, dan indikator bromcresol green-methyl red. Bahan untuk analisis asam amino adalah $\mathrm{HCl} 6 \mathrm{~N}$, Ortoftalaldehida (OPA), $\mathrm{HCl} \mathrm{0,01} \mathrm{N}$, metanol, merkaptoetanol, brij-30 30\%, kertas milipore buffer kalium borat, dan larutan asam amino standar $0,5 \mu \mathrm{mol} / \mathrm{mL}$. Bahan dalam analisis asam lemak digunakan heksana, metanol, kloroform $\left(\mathrm{CHCl}_{3}\right), \mathrm{NaOH}, \mathrm{NaCl}$, dan $\mathrm{BF}_{3}$ $16 \%$.

Alat yang digunakan pada proses penepungan di antaranya pisau, talenan, wadah/baskom, timbangan digital, kompor, panci pengukus, autoklaf, sarung tangan, oven, blender, dan ayakan 60 mesh. Peralatan uji kimiawi (kadar protein) terdiri dari neraca analitik, beaker glass, lemari asam, pipet ukur, labu kjeldahl, buret dan statif, Erlenmeyer, distilator, labu ukur, dan alat destruksi, sedangkan dalam analisis asam amino dengan seperangkat alat High Performance Liquid Chromatography (HPLC), syringe, oven, dan evaporator. Peralatan pengujian kadar lemak yaitu kertas saring, timbangan analitik, soxhlet, labu lemak, oven, pemanas listrik, kapas bebas lemak, dan desikator/eksikator, sedangkan analisis asam lemak menggunakan alat Erlenmeyer, sentrifuse, corong pisah, homogenizer, botol vial, evaporator, dan kromatografi gas (gas chromatography) GCFID.

\section{Metode Penelitian Proses penepungan}

Pembuatan tepung ikan sepat rawa mengacu pada penelitian sebelumnya oleh King (2017); Sunarma (2014); Sari et al. (2014); Saleh (1990) dengan modifikasi. Prosesnya diawali dengan melakukan penyiangan ikan dengan membuang jeroan dan kepala. Selanjutnya dicuci bersih ditimbang dan ditiriskan. Setelah itu ikan dimasukkan ke dalam panci dan autoklaf dimasak sesuai perlakuan yaitu pemasakan menggunakan panci selama 30 menit, autoklaf 20 menit dan autoklaf 30 menit. Setelah itu dilakukan pengepresan dengan cara memerasnya menggunakan kain saring. Kemudian, mengoven selama 12 jam dengan kisaran suhu $50-65^{\circ} \mathrm{C}$. Selanjutnya ikan yang sudah dioven tersebut digiling menggunakan blender kering. Setelah itu dilakukan pengovenan kedua selama 5 jam dengan kisaran suhu 50$65^{\circ} \mathrm{C}$ yang kemudian digiling menggunakan blender kering. Setelah diblender dilakukan pengayakan menggunakan ayakan ukuran 60 mesh.

\section{Prosedur analisis}

Penelitian menggunakan metode Rancangan Acak Lengkap (RAL). Perlakuan yang diberikan adalah pemasakan menggunakan panci selama 30 menit (A), autoklaf 20 menit (B) dan autoklaf 30 menit (C). Analisis kadar protein dengan metode Kjeldahl dan asam amino dengan metode High Performance Liquid Chromatography (HPLC) mengacu pada AOAC (2005), sedangkan untuk analisis kadar lemak dengan metode soxhlet yang mengacu pada SNI (2006). Analisis asam lemak menggunakan Gas Chromatography (GC) berdasarkan pada metode AOAC (2012):969.33

\section{HASIL DAN PEMBAHASAN Kadar Protein Tepung Ikan Sepat Rawa}

Protein merupakan makromolekul penyusun utama hampir semua organisme, 


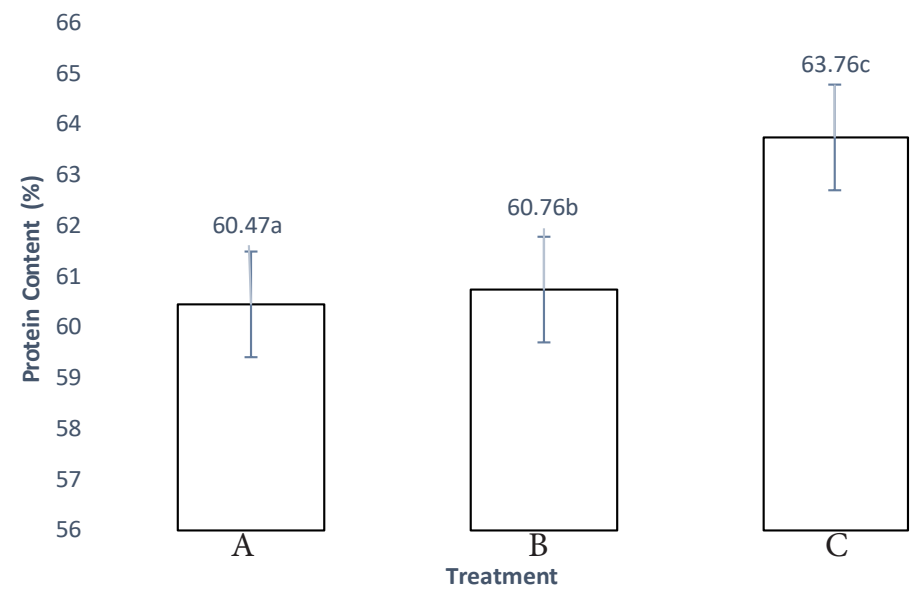

Figure 1 Protein content of Three Spot Gourami (Trichogaster trichopterus) fish flour; (A) 30 minute cooked; (B) 20 minute autoclave cooked; (C) 30 minute autoclave cooked; different letters indicate statistically significant differences $p<0.05$

penyusun utama struktur protein adalah polipeptida yang tersusun dari asam amino (Lehninger 1982). Sumber asam-asam amino adalah protein yang tersusun dari unsur karbon, hidrogen, oksigen, dan nitrogen (Winarno (2008). Hasil analisis protein dengan metode Kjeldahl disajikan pada Figure 1 .

Berdasarkan Figure 1 dapat diketahui kadar protein tepung ikan sepat rawa tertinggi sebesar $63,77 \%$ pada perlakuan C (pemasakan dengan autoklaf lama waktu 30 menit dengan suhu $121^{\circ} \mathrm{C}$ ), kemudian diikuti oleh perlakuan $B$ sebesar $60,76 \%$ (pemasakan dengan autoklaf lama waktu 20 menit dengan suhu $121^{\circ} \mathrm{C}$ ), dan kadar protein tepung ikan sepat rawa terendah sebesar $60,47 \%$ pada perlakuan A sebagai kontrol menerapkan metode pemasakan dengan pengukusan selama 30 menit pada suhu $85-90^{\circ} \mathrm{C}$. Hasil analisis ragam (ANOVA) untuk kadar protein diperoleh hasil $p<0,05$ artinya perlakuan yang diberikan berpengaruh nyata terhadap kandungan protein tepung ikan yang dihasilkan.

Metode pengolahan yang meliputi seluruh rangkaian proses dalam pembuatan tepung ikan juga memberikan pengaruh terhadap kadar protein yang dihasilkan. Proses pemasakan dengan pengukusan dan autoklaf pada suhu yang berbeda antar perlakuan menghasilkan kadar protein yang berbeda pula. Ilza et al. (2000) melaporkan bahwa proses pembuatan tepung ikan memengaruhi kualitas tepung ikan yang dihasilkan. Proses pemasakan ikan menggunakan panci pengukus maupun autoklaf menyebabkan keluarnya air bebas dari dalam bahan pangan. Penguapan air bebas dari bahan tersebut menyebabkan menurunnya kadar air, sehingga dapat meningkatkan kadar protein tepung ikan sepat rawa. Seperti yang dikemukakan oleh Adawyah (2016), kandungan protein di dalam bahan akan mengalami peningkatan apabila kadar air menurun.

Komposisi kimiawi tepung ikan beragam tergantung pada jenis bahan baku, mutu bahan baku, jenis ikan dan cara pengolahannya (Shaviklo et al. 2015; Hiswaty 2002). Berdasarkan hasil analisis kadar protein tepung ikan sepat rawa tertinggi yaitu $63,76 \%$ masih di bawah standar tepung ikan tipe B yaitu minimal kadar protein sebesar 65\% SNI tepung ikan. Kualitas kadar protein tepung ikan sepat rawa yang dihasilkan merupakan tepung ikan tipe C yaitu minimal 60\% berdasarkan standar Food and Agriculture Organization (FAO).

Kadar protein tepung ikan sepat rawa yang dihasilkan lebih tinggi dibandingkan dengan kadar protein tepung ikan sejenis pada penelitian sebelumnya oleh King (2012) yang memilliki rata-rata kadar protein 52,99\%. Kualitas tepung ikan ditinjau dari kadar protein menurut Standar Nasional Indonesia (SNI 2715:2013) mengenai tepung ikan bahan baku pakan, kadar protein tepung ikan sepat 


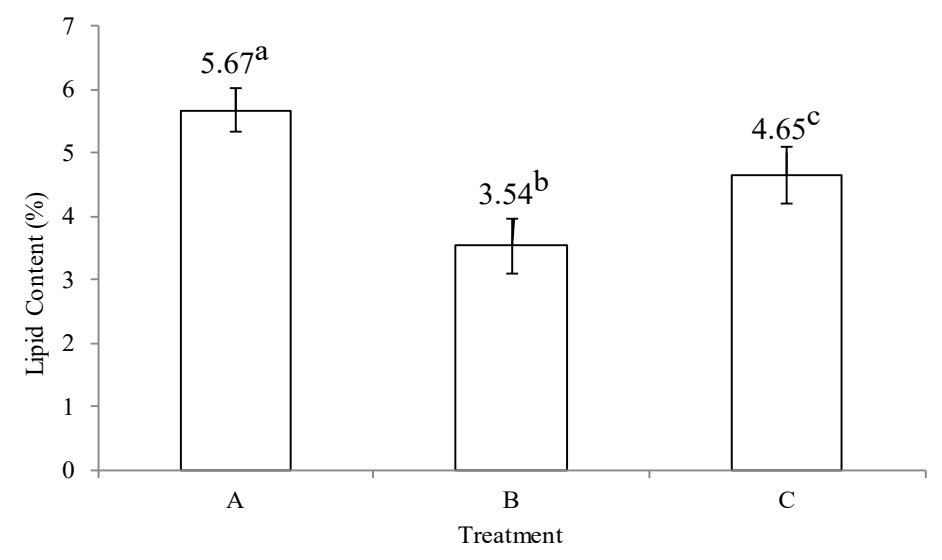

Figure 2 Lipid content of Three Spot Gourami (Trichogaster trichopterus) fish flour; (A) 30 minute cooked; (B) 20 minute autoclave cooked; (C) 30 minute autoclave cooked; different letters indicate statistically significant differences $p<0.05$

rawa tertinggi yaitu $63,76 \%$ termasuk dalam kategori tepung ikan mutu A yaitu dengan standar kadar protein minimal $60 \%$.

\section{Kadar Lemak Tepung Ikan Sepat Rawa}

Hal yang menyebabkan perbedaan sifat fisik minyak (cair) dan lemak (padat) dalam suhu kamar adalah karena adanya pebedaan panjang rantai karbon, jumlah ikatan rangkap dan bentuk trans atau cis yang terkandung pada asam lemaknya (asam lemak tak jenuh). Minyak dan lemak adalah senyawa lipida yang paling banyak ditemukan di alam (Kettaren 1986). Hasil untuk analisis kadar lemak dengan metode soxhlet dapat dilihat pada Figure 2.

Figure 2 menunjukkan bahwa perlakuan B sebesar 5,67\% merupakan perlakuan dengan kadar lemak terendah, kemudian diikuti oleh perlakuan C sebesar $4,65 \%$ dan tepung ikan yang memiliki kadar lemak paling tinggi terdapat pada perlakuan A sebesar 5,67\%. Secara statistik, kadar lemak yang dihasilkan dianalisis dengan analisis ragam (ANOVA) menghasilkan nilai $p<0,05$ yang berarti hipotesis $\mathrm{H}_{1}$ diterima dan $\mathrm{H}_{0}$ ditolak. Dari kesimpulan tersebut berarti perlakuan lama waktu pemasakan yang berbeda terhadap tepung ikan sepat rawa sangat berbeda nyata. Perbedaan yang sangat nyata tersebut karena dipengaruhi oleh lama pemasakan yang mengakibatkan proses perubahan kimiawinya menjadi berbeda serta adanya perbedaan suhu dan tekanan pada perlakuan A (kontrol). Lama waktu dan suhu pada proses pengeringan mengakibatkan kandungan lemak semakin meningkat dan kandungan air yang menurun (Yuniarti et al. 2007)

Kadar lemak tepung ikan sepat rawa yang paling rendah pada perlakuan B 5,67\%. Hasil ini lebih rendah dibandingkan dengan kadar lemak tepung ikan sejenis pada penelitian sebelumnya oleh King (2012) dengan ratarata kadar lemak 10,19\%. Standar Nasional Indonesia (SNI) tepung ikan terdiri dari tiga kategori: kategori A kadar lemak maksimal $10 \%$, kategori B dengan maksimal kadar lemak $11 \%$ dan kategori $\mathrm{C}$ dengan maksimal kadar lemak sebesar 12\% (BSN 2013). Pada masing-masing perlakuan pengolahan tepung ikan sepat rawa menghasilkan kadar lemak yang sudah memenuhi SNI tepung ikan dari segi kadar lemaknya. Dengan demikian tentu tepung ikan sepat rawa dengan semua perlakuannya sudah termasuk ke dalam kategori atau grade A jika diklasifikasikan menurut SNI tepung ikan.

\section{Profil Asam Amino Tepung Ikan Sepat Rawa}

Komponen penyusun protein adalah asam amino yang masing-masing terhubung dengan ikatan peptida, jika dihidrolisis protein akan membentuk asam amino. Kualitas suatu protein dilihat dari perbandingan total asam amino dan jenis-jenis asam amino penyusun protein tersebut. Protein mutunya ditentukan oleh kandungan asam aminonya. Semakin lengkap jenis asam amino semakin 


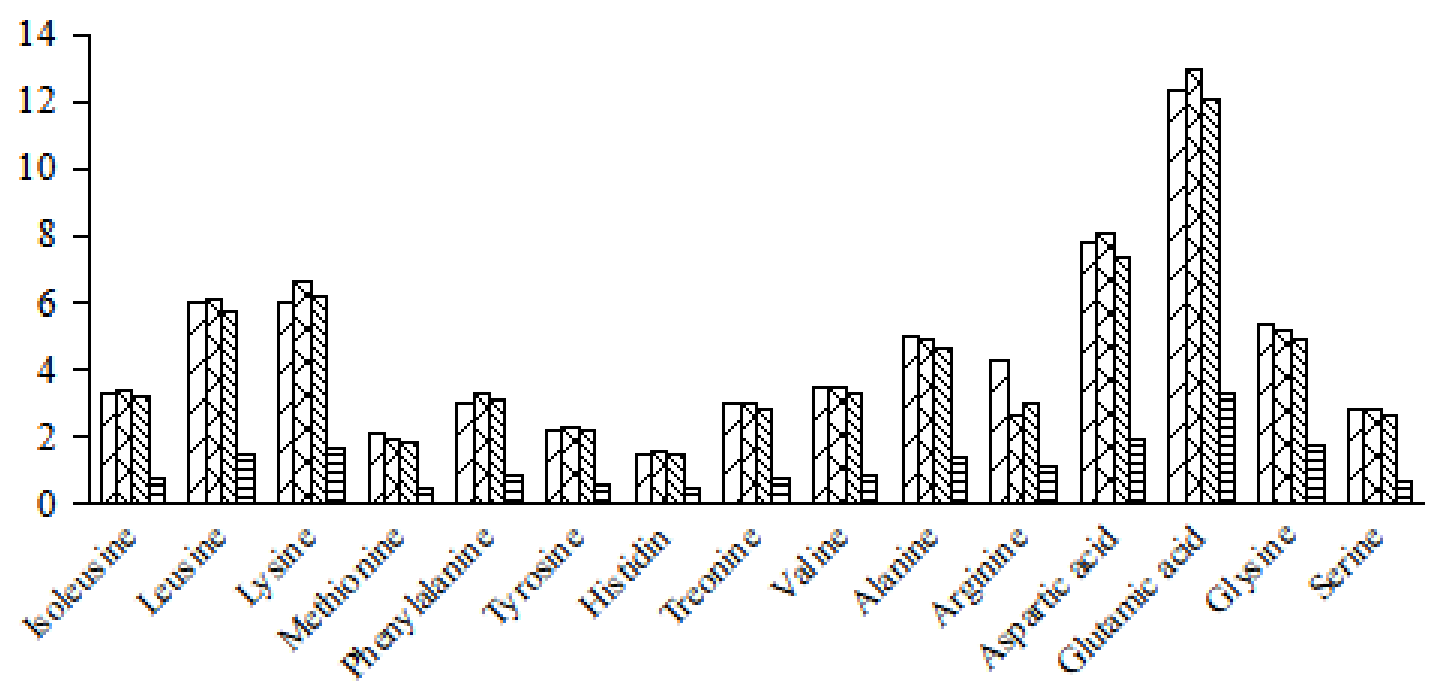

Figure 3 Amino acid profile of Three Spot Gourami (Trichogaster trichopterus) fish flour; $\mid$ A (cooked);

; $\quad \nabla_{\mathrm{B}}$ (20 minutes autoclave); $\mathbb{\mathrm { C }}$ (30 minutes autoclave); 目 D (fresh fish).

baik mutunya dan sesuai proporsinya untuk pertumbuhan (Winarno 2008).

Berdasarkan data hasil penelitian yang diperoleh terdapat 15 jenis asam amino pada tepung ikan sepat rawa yang terdiri atas: isoleusin, leusin, lisin, metionin, fenilalanin, tirosin, histidin, treonin (asam amino esensial) dan valin, alanin, arginin, asam aspartat, asam glutamat, glisin (asam amino non esensial). Hasil analisis asam amino tepung ikan pada berbagai perlakuan disajikan pada Figure 3.

Figure 3 memperlihatkan bahwa asam amino esensial paling tinggi pada tepung ikan sepat rawa hasil dari penelitian ini adalah asam amino lisin yaitu 5,98\% (perlakuan A), 6,66\% (perlakuan B), dan sebesar 6,15\% (perlakuan C). Asam amino esensial terendah yaitu asam amino histidin $1,51 \%$ (perlakuan A), $1,60 \%$ (perlakuan B), dan sebesar $1,46 \%$ (perlakuan C).

Asam amino non esensial paling tinggi pada tepung ikan sepat rawa hasil dari penelitian ini adalah asam glutamat yaitu sebesar 12,33\% (perlakuan A), 12,99\% (perlakuan B), dan sebesar 12,02\% (perlakuan $\mathrm{C})$, sedangkan asam amino non esensial terendah adalah serin 2,85\% (perlakuan A) dan 2,64\% (perlakuan C), dan pada perlakuan $\mathrm{B}$ asam amino non esensial terendah adalah arginin sebesar 2,63\%. Pada tepung ikan cod kandungan asam amino esensial tertinggi adalah asam amino lisin dan terendah histidin sedangkan kandungan asam amino non esensial tertinggi adalah asam amino glutamat dan terendah serin (Desai 2018).

Hasil penelitian ini menunjukkan adanya peningkatan kandungan asam aspartat dan asam glutamat selama proses pengolahan pada suhu dan lama waktu pemasakan tertentu. Peningkatan ini disebabkan terjadinya proses pemanasan pada saat pengukusan dan pemrestoan menggunakan autoklaf yang menyebabkan deaminasi asam amino. Penelitian sebelumnya oleh Utami et al. (2016) dan Putra et al. (2017), membuktikan perbedaan metode pemasakan menyebabkan kandungan asam amino non esensial ikan seluang menjadi meningkat.

\section{Profil Asam Lemak Tepung Ikan Sepat Rawa}

Asam lemak adalah asam organik yang penyusunnya adalah rantai hidrokarbon lurus yang pada satu ujung rantainya terdapat gugus metil $(\mathrm{CH} 3)$ dan ujung satunya lagi terdapat gugus hidroksil (COOH) (Almatsier 2006). Hasil analisis asam lemak dapat dilihat pada Figure 4.

Asam lemak jenuh (SFA) tertinggi yaitu asam palmitat sebesar $21,74 \%$ (perlakuan B), sedangkan asam lemak tak jenuh tunggal (MUFA) tertinggi adalah asam oleat sebesar 


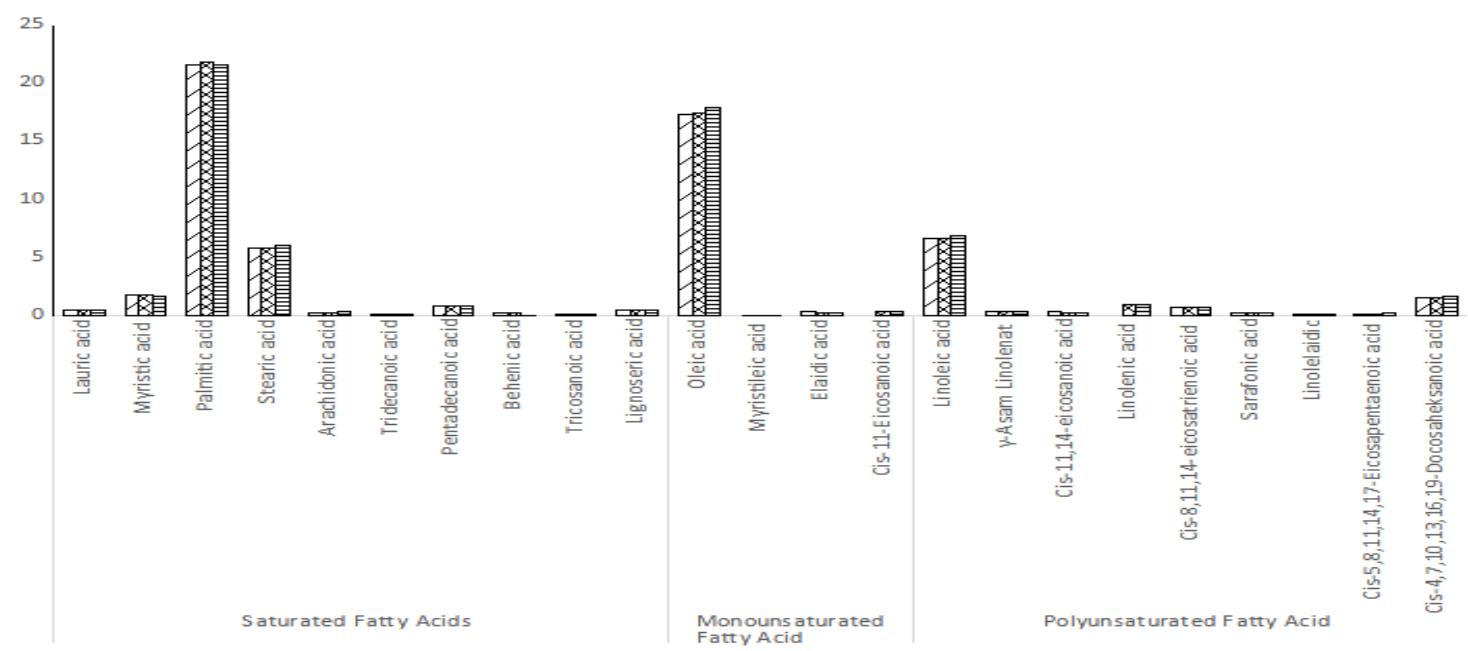

Figure 4 Fatty acid profile of Three Spot Gourami (Trichogaster trichopterus) fish flour; $\mid$ A (cooked);

D B (20 minutes autoclave); 目 C (30 minutes autoclave).

17,89\% (perlakuan C) dan untuk asam lemak tak jenuh jamak (PUFA) tertinggi adalah asam linoleat sebesar 6,88\% (perlakuan C). Kandungan asam lemak pada tepung ikan mas kering tertinggi adalah asam linoleat $46,14 \%$ diikuti oleh asam oleat $27,69 \%$ dan asam palmitat 11,54\%. (Hossam et al. 2017).

Asam palmitat yang merupakan jenis asam lemak paling tinggi pada tepung ikan memiliki beberapa keunggulan dan manfaat. Asam palmitat biasanya terkandung pada minyak kelapa sawit dengan konsentrasi yang relatif tinggi. Kandungan yang demikian mirip dengan apa yang terdapat dalam air susu ibu (ASI). Bahkan menurut Karouw (2014) asam palmitat merupakan asam lemak utama pada komposisi sn-2 ASI, sehingga tepung ikan dengan kandungan asam lemak palmitat yang relatif tinggi ini diduga dapat menjadi alternatif dalam pemenuhan gizi anak dengan melihat kaitannya sebagai zat penyusun ASI yang seharusnya dikonsumsi anak-anak sejak dari lahir.

Asam lemak tak jenuh merupakan komponen yang dominan dalam susunan sel saraf di otak anak. Pertumbuhan dan perkembangan janin, otak dan penglihatan juga sangat dipengaruhi oleh asam lemak esensial. Asam oleat dan asam linoleat merupakan jenis asam lemak tidak jenuh yang banyak terdapat pada tepung ikan sepat rawa yang dihasilkan.
Asam oleat atau biasa disebut sebagai omega 9 dan asam linoleat (omega 6) juga memiliki beberapa keunggulan dan manfaatnya masing-masing. Asam oleat berfungsi sebagai zat antioksidan penghambat kanker, sumber energi dan dapat menurunkan kadar kolestrol. Saat tubuh mengalami kurangnya asam oleat, tubuh akan mengalami gangguan seperti gangguan pada janin dan bayi pertumbuhan sel otak terganggu, gangguan pengelihatan serta menurunnya daya ingat (Al-Saghir et al. 2004). Menurut Orey (2008), minyak zaitun mengandung 55-85\% asam oleat yang berkhasiat dalam penurunan risiko penyakit jantung, mencegah kanker dan sebagainya.

Asam linoleat mempunyai beberapa manfaat di antaranya meningkatkan pertumbuhan otot dan mencegah pemecahan pada otot akibat dari aktivitas. Fungsi lainnya yaitu membantu dalam mengatasi depresi dan penyakit jantung serta efek anti peradangan. Linoleat juga bermanfaat dalam meningkatkan kecerdasan balita, anti peradangan pada sel tubuh, mempertahankan fungsi imun, membran sel dalam pembentukan membran sel otak dan juga memiliki peran yang penting pada transpor dan metabolisme lemak (Diana 2013). 


\section{KESIMPULAN}

Pemasakan dengan lama waktu yang berbeda pada proses pengolahan tepung ikan memberikan pengaruh terhadap kadar protein dan kadar lemak, serta profil asam amino dan asam lemak pada tepung ikan sepat rawa yang dihasilkan. Perlakuan yang terbaik adalah perlakuan $\mathrm{C}$ dengan kadar protein tepung ikan tertinggi $63,77 \%$ dan kadar lemak 4,65\% sudah memenuhi standar SNI.

\section{DAFTAR PUSTAKA}

Adawyah R . 2016. Pengantar Teknologi Hasil Perikanan. Bumi Aksara. Jakarta.

Adeleke RO, Odedeji JO. 2010. Acceptability Studies on Bread Fortified with Tilapia Fish Flour. Pakistan Journal of Nutrition. 9. 10.3923/pjn.2010.531.534.

Almatsier S. 2006. Prinsip Dasar Ilmu Gizi. Jakarta: PT. Gramedia Pustaka Utama.

Al-Saghir S, Thurner K, Wagner KH, Frisch G, Luf W. 2004. Effects of different cooking procedures on lipid quality and cholesterol oxidation of farmed salmon fish (Salmo salar). Journal of Agricultural and Food Chemistry. 52:5290\&5296

[AOAC] Association of Official Analytical Chemist. 2005. Official Method of Analysis of the Association of Official Analytical of Chemist. Virginia (US): The Association of Analytical Chemist, Inc.

Astawan. 2004. Ikan yang Sedap dan Bergizi. Tiga Serangkai. Solo.

[BSN] Badan Standardisasi Nasional. 2006. Penentuan Kadar Total Lemak pada Produk Perikanan. SNI 01-2354.3-2006. Cara Uji Kimia-Bagian 3. Jakarta (ID): Badan Standardisasi Nasional.

[BSN] Badan Standardisasi Nasional. 2013. Tepung Ikan-Bahan Baku Pakan. SNI 2715:2013. Jakarta (ID): Badan Standarisasi Nasional.

Desai AS, Brennan MA, Brennan CS. 2018. Effect of fortification with fish (Pseudophycis bachus) powder on nutritional quality of durum wheat pasta. Foods. 7. 62. 10.3390/foods7040062.

Dinas Perikanan Provinsi Kalimantan Selatan. 2017. Laporan Tahunan Statistik Perikanan Tangkap Provinsi Kalimantan Selatan. Pemerintahan Provinsi Kalimantan
Selatan. Banjarbaru (ID).

Diana FM. 2013. Omega 6. Jurnal Kesehatan Masyarakat. 7(1):26-31

Hiswaty. 2002. Pengaruh Penambahan Tepung Ikan Nila Merah (Oreochromis sp) Terhadap Karakteristik Biskuit. [Skripsi]. Fakultas Perikanan dan Ilmu Kelautan. Bogor (ID): Institut Pertanian Bogor.

Hossam EB, Naglaa ES, Zeinab A, Azza O. 2017. The impact of using chickpea flour and dried carp fish powder on pizza quality. PLOS ONE. 12. e0183657. 10.1371/journal.pone.0183657.

Ilza M, Leksono T, Syahrul. 2000. Studi pengaruh cara pemasakan terhadap mutu tepung ikan. Jurnal Peternakan dan Lingkungan. 6(22): 43-49.

Jacoeb AM, Nurjanah, Lingga LA Br. 2012. Karakteristik protein dan asam amino daging rajungan (Portunus pelagicus) akibat pengukusan. Jurnal Pengolahan Hasil Perikanan Indonesia. 15(2):156-163

Jacoeb AM, Hamdani M, Nurjanah. 2008. Perubahan komposisi kimia dan vitamin daging udang ronggeng (Harpiosquilla raphidea) akibat perebusan. Buletin Teknologi Hasil Perikanan. 11(2):76-88.

Jacoeb AM, Nurjanah, Saraswati A. 2013. Kandungan asam lemak dan kolesterol kakap merah (Lutjanus bohar) setelah pengukusan. Jurnal Pengolahan Hasil Perikanan Indonesia. 16(2):168-176.

Karouw S. 2014. Pemanfaatan stearin sawit dan minyak kelapa untuk formulasi asam lemak mirip asi. Jurnal perspektif. 13(2):63.

Ketaren NS. 1986. Pengantar Teknologi Minyak dan Lemak Pangan. Cetakan pertama. Jakarta: UI Press.

King DES. 2017. Pengaruh Penambahan Tepung Ikan Sepat Rawa (Trichogaster trichopterus Pall) Terhadap Kualitas Kue Kering. [Skripsi]. Fakultas Perikanan dan Kelautan Universitas Lambung Mangkurat. Banjarbaru (ID): Universitas Lambung Mangkurat.

Kusumaningrum I, Sutono D, Pamungkas BF. 2016. Pemanfaatan tulang ikan belida sebagai tepung sumber kalsium dengan metode alkali. Jurnal Pengolahan Hasil Perikanan Indonesia. 19(2): 148-155. 
Larsen R. Eilersten KE. and Elvevoll EO. 2011. Health benefits of marine foods and ingredients. Biotechnology Advances. 29:508-518.

Lehninger LA 1982. Dasar-dasar Biokimia. PT Gelora Aksara Pratama. Jakarta.

Liputo, Siti AS, Berhimpon, Feti F. 2013. Analisa nilai gizi serta komponen asam amino dan asam lemak dari nugget ikan nike (Awaous melanocephalus) dengan penambahan tempe. Chemistry Progress. 6(1):38-44

Murjani A. 2011. Budidaya beberapa varietas ikan sepat rawa (Trichogaster trichopterus Pall) dengan pemberian pakan komersial. Fish Scientiae. 1(2):214-232.

Nurilmala M, Suptijah P, Subagja Y, Hidayat T. 2014. Pemanfaatan dan fortifkasi ikan patin pada snack ekstrusi. Jurnal Pengolahan Hasil Perikanan Indonesia. 17(2):175-185.

Nurjanah, Suseno SH, Hidayat T, Paramudhita PS, Ekawati Y, Arifianto TB. 2015. Changes in nutritional composition of skipjack (Katsuwonus pelamis) due to frying process. International Food Research Journal . 22(5): 2093-2102

Orey, Cal. 2008. Khasiat Minyak Zaitun Resep Umur Panjang Ala Mediterania. Jakarta: Hikmah.

Ozugul Y, Ozugul F. 2007. Fatty acid profiles of commercially important fish species from the mediterranean, agean dan black seas. Food Chemistry. 100(4): 1634-1638.

Pratiwi F. 2013. Pemanfaatan Tepung Daging Ikan Layang untuk Pembuatan Stick Ikan. Jurusan Teknologi Jasa dan Produksi. Semarang (ID): Universitas Negeri Semarang.

Riry Johan, Lawalata1 VN, Tapotubun EJ, FarFar1 RA. 2016. Mutu organoleptik produk enbal fortifikasi (makanan tradisional Kepulauan Kei) ditinjau dari daya terima konsumen. Jurnal Pengolahan Hasil Perikanan Indonesia. 16(3):259-267

Saleh M. 1990. Pengaruh pengepresan, mutu bahan mentah dan lama penyimpanan terhadap mutu tepung ikan. Jurnal Penelitian Pasca Panen Perikanan. 65: 41 52.

Saparinto C. 2007. Membuat Aneka Olahan Bandeng. Jakarta: Penebar Swadaya.

Sari DK, Rahmawati H, Susilawati. 2019. Stik sepat siam (Trichogaster pectoralis) tinggi protein dan kalsium sebagai diversifikasi olahan hasil perikanan. Jurnal Pengolahan Hasil Perikanan Indonesia. 22(2): 311-317

Sari DK, Marliyati SA, Kustiyah L, Khomsan A, Gantohe TM. 2014. Uji organoleptik formulasi biskuit fungsional berbasis tepung ikan gabus (Ophiocephalus striatus). Agritech. 34(2): 120-125.

Shaviklo AR. 2015. Development of fish protein powder as an ingredient for food applications: A Review. Journal Food Scientists and Technology. 52(2):649.

Sunarma AFF. 2014. Substitusi Tepung Tulang Ikan Sebagai Sumber Kalsium pada Produk Bakso Ikan Patin (Pangasius sp.). [Skripsi]. Fakultas Perikanan dan Kelautan. Banjarbaru (ID): Universitas Lambung Mangkurat.

Winarno FG. 2008. Kimia Pangan dan Gizi. PT. Gramedia Pustaka Utama. Jakarta.

Yenni, Nurhayati T, Nurjanah. 2012. Pengaruh perebusan terhadap kandungan asam lemak dan kolesterol kerang pokea (Batissa violacea celebensis Marten 1897). Jurnal Pengolahan Hasil Perikanan Indonesia. 15(3):193-198 